ANNALES

UNIVERSITATIS MARIAE CURIE-SKŁODOWSKA LUBLIN - POLONIA

\title{
The simultaneous voltammetry determination of cadmium(II) and lead(II) at bismuth film glassy carbon electode prepared with the use of mediator
}

\author{
Katarzyna Domańska*, Katarzyna Tyszczuk-Rotko \\ and Sabina Dąbal \\ Department of Analytical Chemistry and Instrumental Analysis, \\ Faculty of Chemistry, Maria Curie-Skłodowska University \\ Maria Curie-Skłodowska Sq. 3, 20-031 Lublin \\ email:domanska.k91@gmail.com
}

This paper shows a novel, simple and rapid voltammetric procedure, which enables $\mathrm{Cd}$ and $\mathrm{Pb}$ determination at traces concentrations. All measurements were carried out by differential pulse anodic stripping voltammetry (DPASV) with total time of analysis of $210 \mathrm{~s}$. The obtained detection limits were $8.46 \cdot 10^{-10} \mathrm{~mol} / \mathrm{dm}^{3}$ and $2.57 \cdot 10^{-10} \mathrm{~mol} / \mathrm{dm}^{3}$ for $\mathrm{Cd}(\mathrm{II})$ and $\mathrm{Pb}(\mathrm{II})$, respectively. This procedure was successfully applied for the quantification of mentioned metal ions in water samples collected from the Vistula River.

\section{INTRODUCTION}

The contamination of heavy metals in the environment has dramatically increased during last 50 years [1]. The main reasons for this are industrial development including the extensive use of heavy metals in technological processes and anthropogenic activities $[2,3]$. The presence of heavy metal ions in natural environment (in the air, water and soil) causes that they get to the food chain and they are easily collected by organisms [2]. Furthermore, they are hazardous because they are hardly 
biodegradable and difficult to remove [4]. Heavy metals constitute particular threat for living organisms especially due to their high toxicity and tendency to bioaccumulation in animal and human organisms [5].

Two of the most toxic heavy metals are cadmium and lead [6]. Cadmium causes pulmonary and stomach irritation especially when it is taken in high dose. Then the following symptoms appear: vomiting, vertigo, muscle cramps, abdominal pain and loss of consciousness [7]. Cadmium is able to accumulate in some organs such as the kidneys, the liver and the bones. Long-term exposure to Cd(II) lead to morphological changes in the kidneys, skeletal demineralization (osteoporosis), cardiovascular diseases and it contribute to the tumor formation in the kidneys, the lungs and the prostate $[8,9]$. Lead has dangerous influence especially on the nervous system. Lead poisoning causes irritability, headache and memory deterioration $[10,11]$. It also has hazardous effect on the liver, the kidney, the brain, endocrine, reproductive and hematopoietic system [7, 12]. Probably, it is associated with the lungs cancer, gliomas, the prostate and the stomach cancer [13, 14]. Especially susceptible to lead effects are children under 6 years old, because their blood-brain barrier is not fully developed and lead impacts on nervous and circulatory at lower threshold levels in comparison to adult [15]. Due to high toxicity and easy circulation it is needed to develop analytical method for trace determination of heavy metal ions in environmental and food samples [16].

Electrochemical methods', especially stripping voltammetry, is an appropriate technique for trace heavy metal ions detection [17]. It is a convenient method due to a low cost, an easy operation and high sensitivity [18]. One of the most important in voltammetry is selection of a suitable electrode material. It has influence on reproducibility, selectivity and sensitivity of the measurement [19]. For many years mercury electrodes for the determination of heavy metal ions were widely used [20]. However, their toxicity caused that scientists began to look for environmentally friendly modifier of the electrodes [21]. Bismuth complies with these requirements. Bismuth-modified electrodes have a lot of advantages. It includes a simple preparation, very low toxicity, high sensitivity, well separated analytical signals and simple electrode preparation [22]. Likewise, bismuth-based electrodes are able to form „fused" alloy with other metals, what is similar to mercury [18]. In this study, a simple, fast and sensitive procedure for $\mathrm{Cd}$ (II) and $\mathrm{Pb}$ (II) determination at a bismuth film glassy carbon electrode prepared with the use of a reversible deposited mediator ( $\mathrm{Zn}$ ) is shown. 


\section{EXPERIMENTAL}

\subsection{Apparatus and electrodes}

Differential pulse anodic stripping voltammetric (DPASV) measurements were carried out with the use of $\mu$ Autolab analyzer (Eco Chemie, Netherlands) connected to a computer equipped with USB electrochemical interface and driven via a GPES 4.9 software package (Eco Chemie, Netherlands). The classic quartz cell with the volume of $10 \mathrm{~cm}^{3}$ was used. The electrochemical cell comprised three-electrode system includes a silver/silver chloride/potassium chloride $(\mathrm{Ag} / \mathrm{AgCl} / \mathrm{KCl}$ $3 \mathrm{~mol} / \mathrm{dm}^{3}$ ) as the reference electrode, a platinum wire as the counter electrode and the bismuth film glassy carbon electrode as the working electrode. The glassy carbon surface was polished daily with the use of $0.05 \mu \mathrm{m}, 0.3 \mu \mathrm{m}, 1 \mu \mathrm{m}$ and alumina slurry on a Buehler polishing pad with following washing and sonication for $1 \mathrm{~min}$.

\subsection{Reagents and water sample}

$1 \mathrm{~mol} / \mathrm{dm}^{3}$ acetic buffer was prepared from $\mathrm{CHCOONH}_{4}$ and $\mathrm{HCl}$ (30\%, Suprapur) obtained from Sigma-Aldrich. The stock standard solutions of $\mathrm{Bi}(\mathrm{III}), \mathrm{Zn}(\mathrm{II}), \mathrm{Pb}(\mathrm{II})$ and $\mathrm{Cd}(\mathrm{II})\left(1 \mathrm{~g} / \mathrm{dm}^{3}\right)$ were purchased from Merck. The working solutions of $\mathrm{Bi}(\mathrm{III}), \mathrm{Zn}$ (II), $\mathrm{Pb}$ (II) and $\mathrm{Cd}$ (II) were prepared from stock standard solution with appropriate dilution in $0.1 \mathrm{~mol} / \mathrm{dm}^{3} \mathrm{HNO}_{3}$ (Merck). Ultra-purified water $(>18 \mathrm{M} \Omega \mathrm{cm}$ ) supplied by a Milli-Q system (Millipore, UK) was applied for all solutions preparation.

The river water sample was collected from the Vistula River (Pulawy, Poland) and it was filtered using a $0.45 \mu \mathrm{m}$ Milipore filter. Then it was acidified to $\mathrm{pH}=2$ using concentrated $\mathrm{HNO}_{3}$ and mineralized by $3 \mathrm{~h}$ with the use of UV-digester (Mineral, Poland).

\subsection{The voltammetric procedure}

All measurements were performed in a solution contained $0.05 \mathrm{~mol} / \mathrm{dm}^{3}$ acetic buffer $(\mathrm{pH}=3.8)$ as a supporting electrolyte, $7.5 \cdot 10^{-6} \mathrm{~mol} / \mathrm{dm}^{3} \mathrm{Bi}(\mathrm{III})$ and $2.5 \cdot 10^{-6} \mathrm{~mol} / \mathrm{dm}^{3} \mathrm{Zn}$ (II) and increasing concentration of $\mathrm{Cd}(\mathrm{II})$ and $\mathrm{Pb}(\mathrm{II})$. The glassy carbon electrode was the bismuth film in situ plated with the use of a reversibly deposited mediator ( $\mathrm{Zn})$. In the first step, at a potential of $-1.5 \mathrm{~V}$ for $180 \mathrm{~s} \mathrm{Bi}, \mathrm{Zn}, \mathrm{Cd}$ and $\mathrm{Pb}$ were simultaneously deposited onto the glassy carbon surface. Then, the 
potential was changed to the value of $-1.05 \mathrm{~V}$ for $30 \mathrm{~s}$. In this step, zinc was stripped from the surface, while bismuth, lead and cadmium continued to be deposited. Within the both steps, the solution was stirring with the use of a stirring bar. Afterwards, the stirring was stopped for $5 \mathrm{~s}$ and the differential pulse voltammograms were recorded in the range from -1.05 to $-0.2 \mathrm{~V}$. The measurements were carried out utilizing nondeaerated solutions.

\section{RESULTS AND DISCUSSION}

\subsection{The comparison of electrodes}

The effect of electrode modification on the analytical signal of $2 \cdot 10^{-7} \mathrm{~mol} / \mathrm{dm}^{3} \mathrm{Cd}$ (II) and $5 \cdot 10^{-8} \mathrm{~mol} / \mathrm{dm}^{3} \mathrm{~Pb}$ (II) was performed. Two types of electrodes were investigated: (a) bismuth film glassy carbon electrode modified without, and (b) with the use of a zinc mediator.

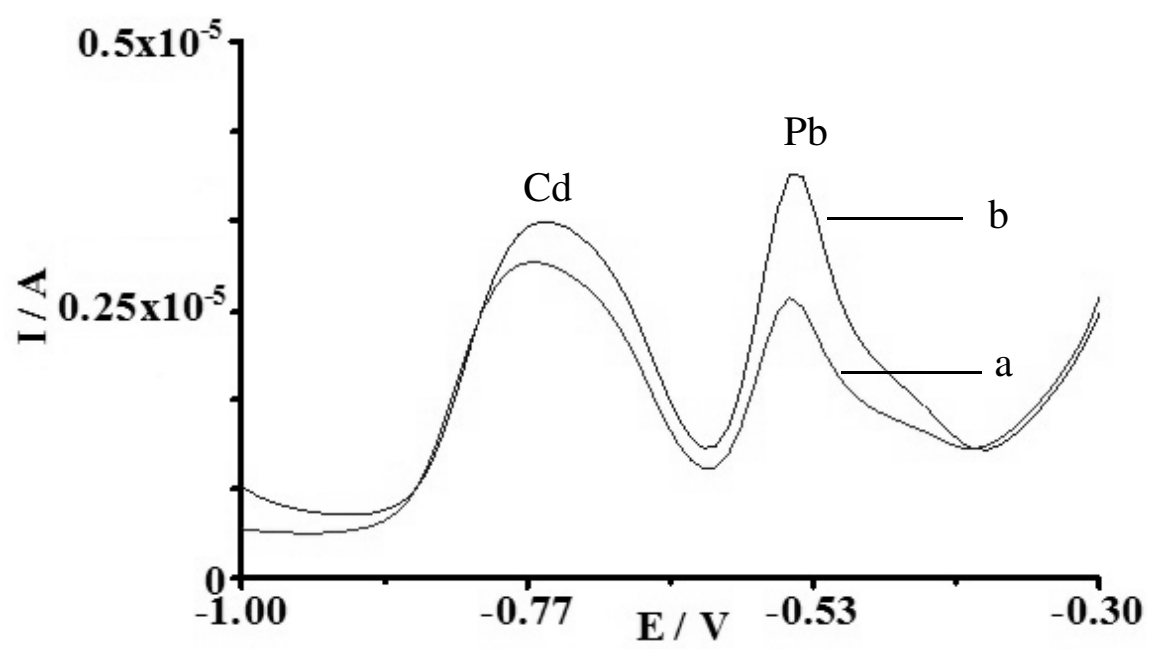

Fig. 1. Square wave voltammograms obtained at: bismuth film glassy carbon electrode modified without (a) and with (b) the use of a zinc mediator. Concentrations of $\mathrm{Cd}(\mathrm{II})$ and $\mathrm{Pb}$ (II) were $2 \cdot 10^{-7}$ and $5 \cdot 10^{-8} \mathrm{~mol} / \mathrm{dm}^{3}$, respectively and were determined in solution contained $0.05 \mathrm{~mol} / \mathrm{dm}^{3}$ acetate buffer solution $(\mathrm{pH}=3.8), 2 \cdot 10^{-5} \mathrm{~mol} / \mathrm{dm}^{3} \mathrm{Bi}(\mathrm{III})$ and 0 (a) or $2 \cdot 10^{-5} \mathrm{~mol} / \mathrm{dm}^{3} \mathrm{Zn}(\mathrm{II})$ (b). Bi, $\mathrm{Zn}, \mathrm{Cd}$ and $\mathrm{Pb}$ were deposited at $-1.65 \mathrm{~V}$ for $180 \mathrm{~s}$ and oxidizing of $\mathrm{Zn}$ were conducted at potential of $-0.95 \mathrm{~V}$ for $10 \mathrm{~s}$. Square wave woltammograms were registered from -1.65 to $0.5 \mathrm{~V}$.

The obtained results are shown in the Figure 1 and they prove that the use of the zinc mediator causes significant $\mathrm{Pb}$ (II) peak current 
increase from $1.29 \mu \mathrm{A}$ to $2.70 \mu \mathrm{A}$ and slight influence on the $\mathrm{Cd}(\mathrm{II})$ peak current. Growth of $\mathrm{Cd}$ (II) peak height from $2.25 \mu \mathrm{A}$ to $2.45 \mu \mathrm{A}$ was observed. Therefore, the bismuth film glassy carbon electrode modified with the use of mediator was chosen for the further studies.

\subsection{The optimization of conditions and parameters for $C d(I I)$ and $P b(I I)$ determination}

The effect of the working electrode modification with the bismuth film and influence of a zinc mediator on the analytical signal of $\mathrm{Cd}$ (II) and $\mathrm{Pb}(\mathrm{II})$ were investigated. Moreover, voltammetric technique type, $\mathrm{Bi}(\mathrm{III})$ and $\mathrm{Zn}$ (II) contaminations, the deposition time and potential of $\mathrm{Bi}$, $\mathrm{Zn}, \mathrm{Cd}$ and $\mathrm{Pb}$ as well as the time and potential of $\mathrm{Zn}$ stripping from the electrode surface were checked.

\subsubsection{The impact of voltammetric technique type}

The influence of voltammetric technique type was investigated. Voltammetric measurements were carried out for concentration of $\mathrm{Cd}$ (II) and $\mathrm{Pb}$ (II) equal to $2 \cdot 10^{-7} \mathrm{~mol} / \mathrm{dm}^{3}$ and $5 \cdot 10^{-8} \mathrm{~mol} / \mathrm{dm}^{3}$, respectively. Two voltammetric techniques were compared: differential pulse voltammetry (DPV) and square wave voltammetry (SWV). The Cd(II) and $\mathrm{Pb}$ (II) peaks height obtained with the use of SWV were greater, but that obtained with the use of DPV were much better shaped, so for further studies DPV technique was chosen.

\subsubsection{The composition of measurement solution}

In this part of experiments, the effect of $\mathrm{Bi}(\mathrm{III})$ concentration on the analytical signals of $\mathrm{Cd}(\mathrm{II})$ and $\mathrm{Pb}$ (II) was investigated. The concentration range of $\mathrm{Bi}$ (III) from $2.5 \cdot 10^{-6} \mathrm{~mol} / \mathrm{dm}^{3}$ to $1 \cdot 10^{-5} \mathrm{~mol} / \mathrm{dm}^{3}$ was tested. The results show that the concentration of $\mathrm{Bi}(\mathrm{III})$ affects on the peak currents of studied ions and the largest signal of $\mathrm{Cd}(\mathrm{II})$ was obtained for $7.5 \cdot 10^{-6} \mathrm{~mol} / \mathrm{dm}^{3} \mathrm{Bi}(\mathrm{III})$ and for a higher concentration of $\mathrm{Bi}(\mathrm{III})$, the lead peak current was still increasing. Due to the decrese of the $\mathrm{Cd}$ (II) peak current and the fact that obtained analytical signals of cadmium had worse quality, the concentration $7.5 \cdot 10^{-6} \mathrm{~mol} / \mathrm{dm}^{3}$ of $\mathrm{Bi}$ (III) was considered as optimal (Fig. 2 A).

The use of mediator during the deposition of electrode modifier metal causes the analytical signal enhancement of both metal ions $[23,24]$ and organic compounds [25]. This effect depends on the mediator concentration, in this case $\mathrm{Zn}(\mathrm{II})$. The concentration of $\mathrm{Zn}$ (II) was 
changed from 0 to $2 \cdot 10^{-5} \mathrm{~mol} / \mathrm{dm}^{3}$ and for $2.5 \cdot 10^{-6} \mathrm{~mol} / \mathrm{dm}^{3}$ the cadmium(II) peak was the highest. For higher concentration of $\mathrm{Zn}(\mathrm{II})$ the peak current of $\mathrm{Pb}$ (II) was still increasing, but the peak current of $\mathrm{Cd}$ (II) was decreased (Fig. $2 \mathrm{~B}$ ). Werefore, $2.5 \cdot 10^{-6} \mathrm{~mol} / \mathrm{dm}^{3}$ was chosen as an optimal concentration of $\mathrm{Zn}(\mathrm{II})$.
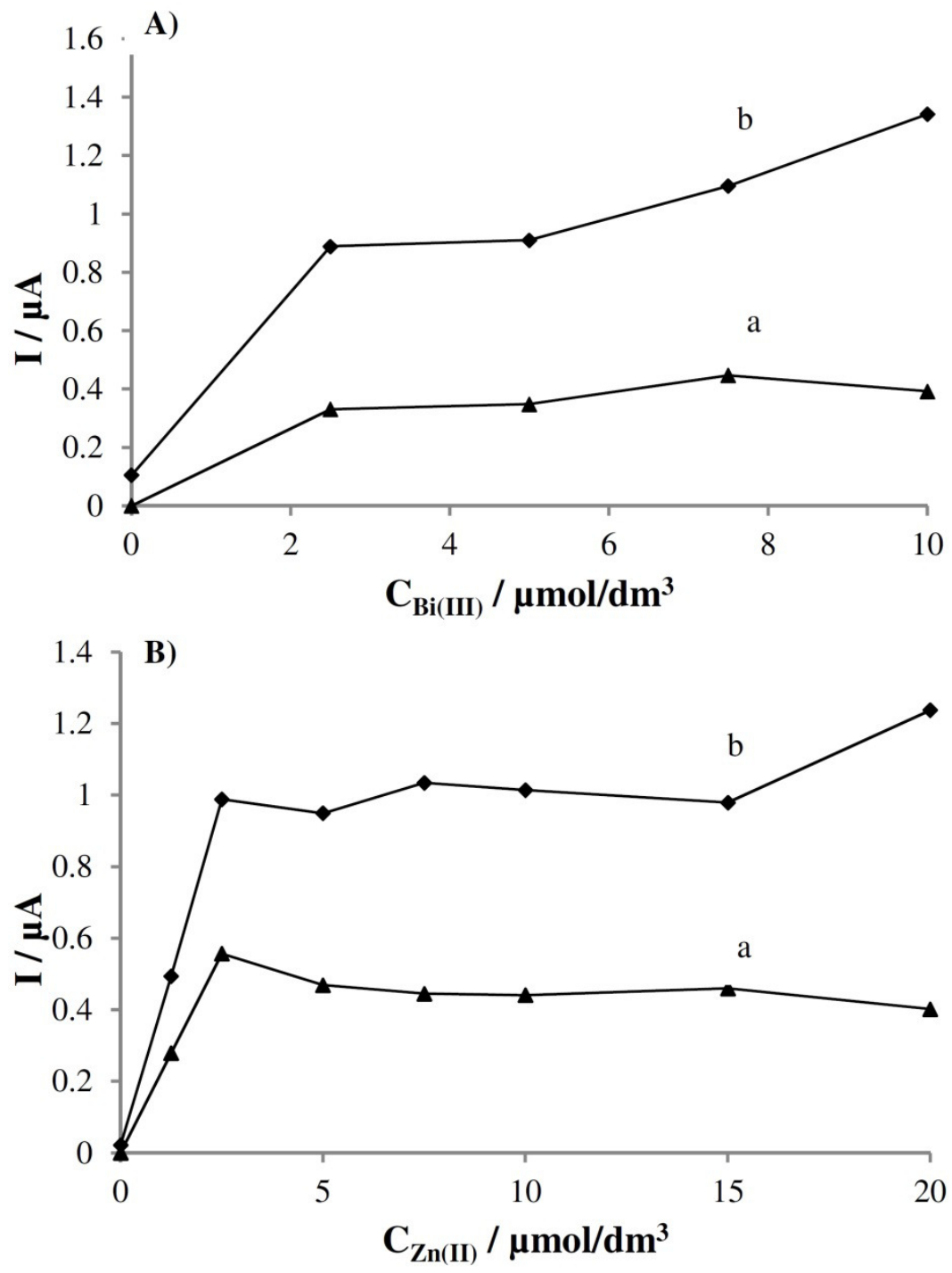

Fig. 2. The influence of: A) Bi(III) and B) $\mathrm{Zn}(\mathrm{II})$ concentration on the peak currents of $\mathrm{Cd}(\mathrm{II})$ (a) and $\mathrm{Pb}$ (II) (b). The solution contained $0.05 \mathrm{~mol} / \mathrm{dm}^{3}$ acetate buffer $(\mathrm{pH}=3.8), 2 \cdot 10^{-5} \mathrm{~mol} / \mathrm{dm}^{3} \mathrm{Zn}(\mathrm{II})(\mathrm{A}), 7.5 \cdot 10^{-6} \mathrm{~mol} / \mathrm{dm}^{3}$ $\mathrm{Bi}(\mathrm{III})(\mathrm{B}), 2 \cdot 10^{-7} \mathrm{~mol} / \mathrm{dm}^{3} \mathrm{Cd}$ (II) and $5 \cdot 10^{-8} \mathrm{~mol} / \mathrm{dm}^{3} \mathrm{~Pb}(\mathrm{II})$. 


\subsubsection{The influence of procedure parametres}

The influence of bismuth, zinc, cadmium and lead deposition potential was verified in the range from -1.8 to $-1.2 \mathrm{~V}$ for $2 \cdot 10^{-7} \mathrm{~mol} / \mathrm{dm}^{3}$ of $\mathrm{Cd}(\mathrm{II})$ and $5 \cdot 10^{-8} \mathrm{~mol} / \mathrm{dm}^{3}$ of $\mathrm{Pb}$ (II).
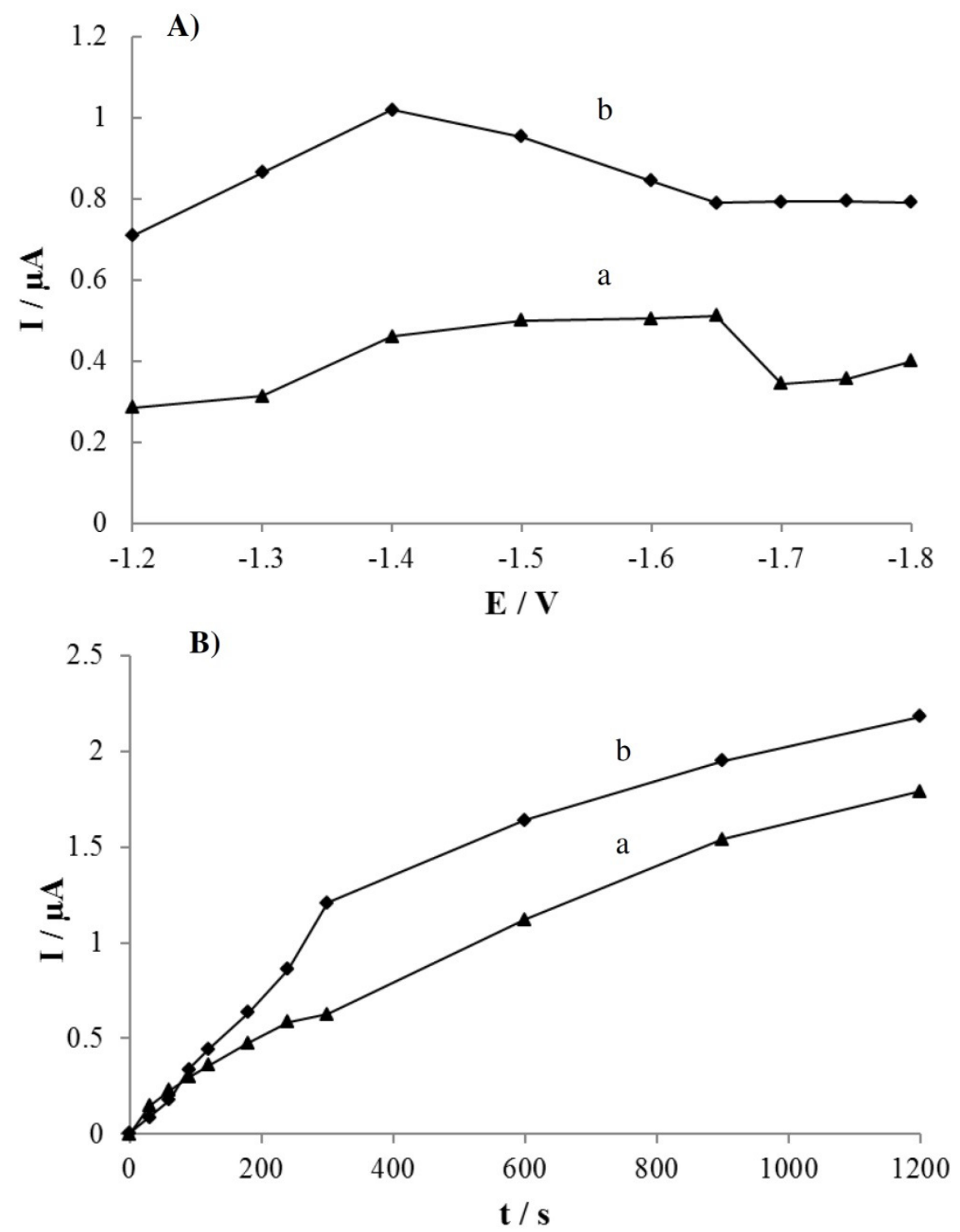

Fig. 3. The influence of $\mathrm{Bi}, \mathrm{Zn}, \mathrm{Cd}$ and $\mathrm{Pb}$ deposition potential (A) and time (B) on the analytical signals of $\mathrm{Cd}(\mathrm{II})$ (a) and $\mathrm{Pb}$ (II) (b). The solution contained $0.05 \mathrm{~mol} / \mathrm{dm}^{3}$ acetate buffer $(\mathrm{pH}=3.8), 7.5 \cdot 10^{-6} \mathrm{~mol} / \mathrm{dm}^{3} \mathrm{Bi}(\mathrm{III})$, $2.5 \cdot 10^{-6} \mathrm{~mol} / \mathrm{dm}^{3} \mathrm{Zn}(\mathrm{II}), 2 \cdot 10^{-7} \mathrm{~mol} / \mathrm{dm}^{3} \mathrm{Cd}(\mathrm{II})$ and $5 \cdot 10^{-8} \mathrm{~mol} / \mathrm{dm}^{3}$ $\mathrm{Pb}(\mathrm{II})$. The deposition time and potential of $\mathrm{Bi}, \mathrm{Zn}, \mathrm{Cd}$ and $\mathrm{Pb}$ were $180 \mathrm{~s}$ (A) and $-1.5 \mathrm{~V}(\mathrm{~B})$, respectively. 
As it can be seen in Fig. 3A, within the potential range from -1.4 to $-1.65 \mathrm{~V}$ the lead(II) peak current was decreasing while the increase of cadmium(II) peak height was observed. For this reason, potential of $-1.5 \mathrm{~V}$ was recognized as the optimal value taking into account the height of both peaks and it was chosen for the further studies. Whereas, the deposition time of $\mathrm{Bi}, \mathrm{Zn}, \mathrm{Cd}$ and $\mathrm{Pb}$ was changed from 0 to $1200 \mathrm{~s}$ and its influence on the cadmium and lead peaks was studied (Fig. 3 B). The maximum currents were obtained within $1200 \mathrm{~s}$, but in order to reduce the total time of analysis, the time of $180 \mathrm{~s}$ was chosen.

In the next part of experiments, the influence of $\mathrm{Zn}$ oxidation and further $\mathrm{Bi}, \mathrm{Cd}$ and $\mathrm{Pb}$ deposition potential and time on the $\mathrm{Cd}(\mathrm{II})$ and $\mathrm{Pb}$ (II) peak currents were investigated. It was studied for the concentrations of $\mathrm{Cd}$ (II) and $\mathrm{Pb}$ (II) equal to $2 \cdot 10^{-7} \mathrm{~mol} / \mathrm{dm}^{3}$ and $5 \cdot 10^{-8} \mathrm{~mol} / \mathrm{dm}^{3}$, respectively. The potential was changed in the range from -1.2 to $-0.8 \mathrm{~V}$ and time was extended from 0 to $60 \mathrm{~s}$. In the range from -0.9 to $-1.1 \mathrm{~V}$ the $\mathrm{Cd}(\mathrm{II})$ peak height did not change. The most satisfying results were obtained for the potential of $-1.05 \mathrm{~V}$ due to the maximum of $\mathrm{Pb}$ (II) peak current (Fig. 4 A). Time of $30 \mathrm{~s}$ was chosen in order to total remove $\mathrm{Zn}$ from the working electrode surface and the largest increase of $\mathrm{Pb}(\mathrm{II})$ peak current (Fig. 4 B).

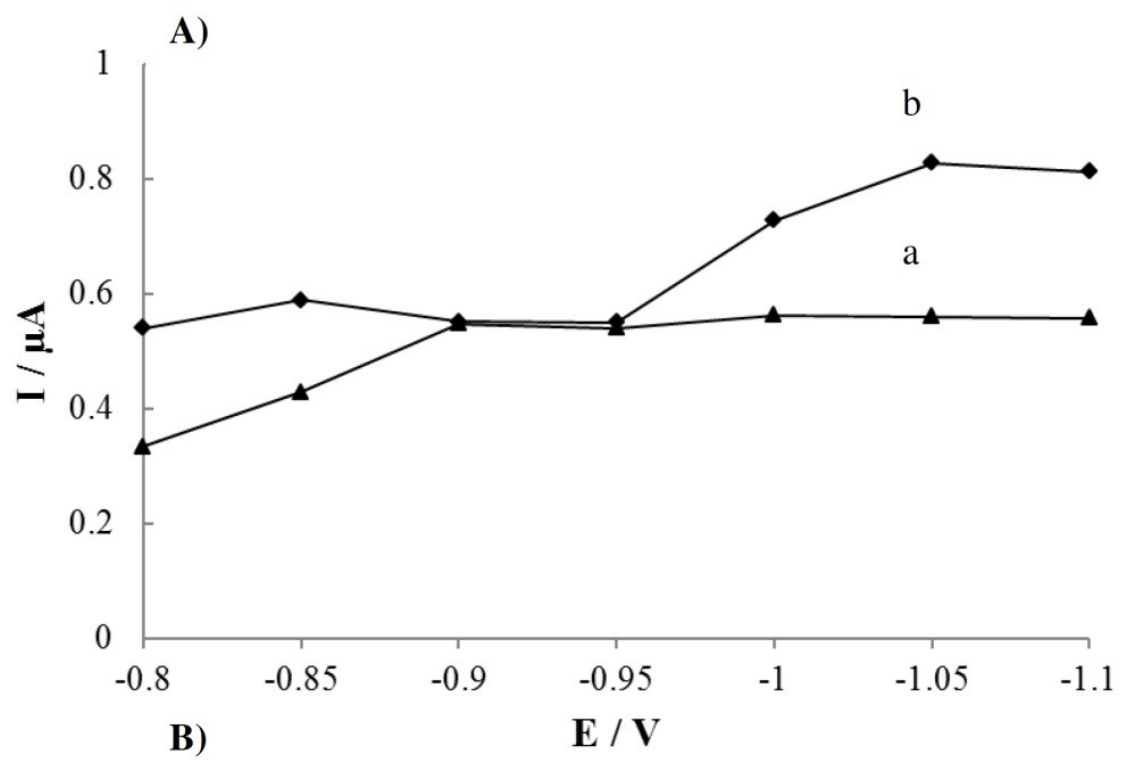




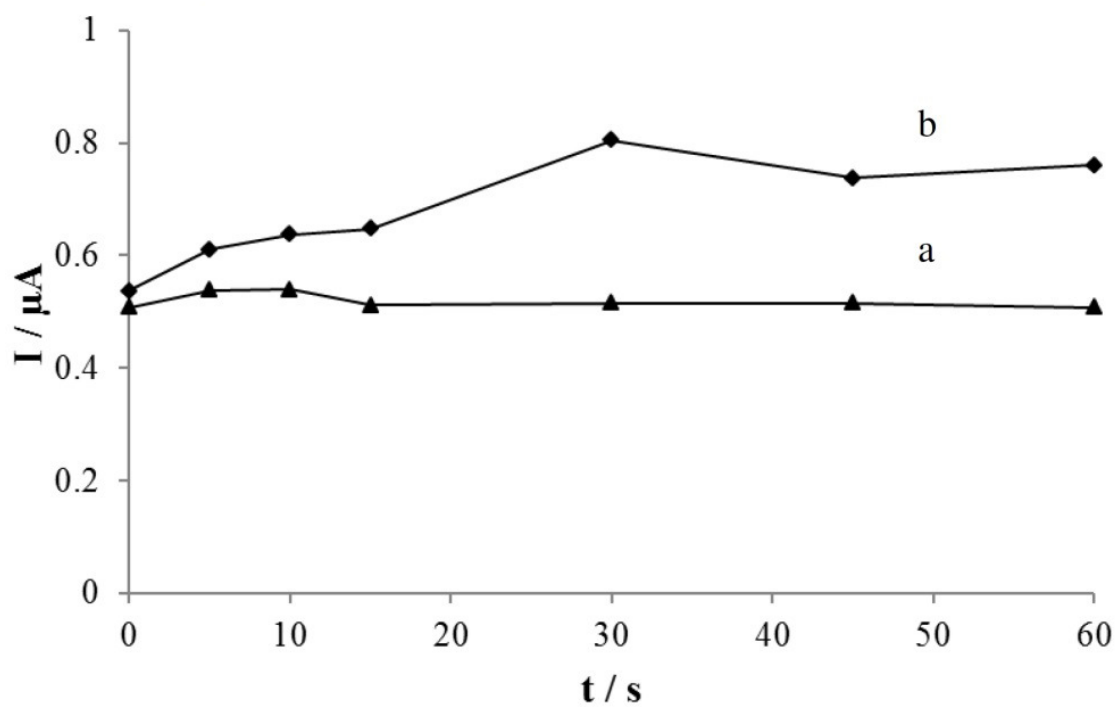

Fig. 4. The influence of potential (A) and time (B) of $\mathrm{Zn}$ oxidation and further $\mathrm{Bi}, \mathrm{Cd}$ and $\mathrm{Pb}$ deposition on the analytical signals of $\mathrm{Cd}(\mathrm{II})$ (a) and $\mathrm{Pb}$ (II) (b). The solution contained $0.05 \mathrm{~mol} / \mathrm{dm}^{3}$ acetate buffer $(\mathrm{pH}=3.8)$, $7.5 \cdot 10^{-6} \mathrm{~mol} / \mathrm{dm}^{3} \mathrm{Bi}(\mathrm{III}), 2.5 \cdot 10^{-6} \mathrm{~mol} / \mathrm{dm}^{3} \mathrm{Zn}(\mathrm{II}), 2 \cdot 10^{-7} \mathrm{~mol} / \mathrm{dm}^{3}$ $\mathrm{Cd}(\mathrm{II})$ and $5 \cdot 10^{-8} \mathrm{~mol} / \mathrm{dm}^{3} \mathrm{~Pb}$ (II). The time and potential of $\mathrm{Zn}$ oxidation and further $\mathrm{Bi}, \mathrm{Cd}, \mathrm{Pb}$ deposition were $10 \mathrm{~s}(\mathrm{~A})$ and $-1.05 \mathrm{~V}$ (B), respectively.

\subsection{Calibration graph}

The measurements for calibration graphs for the simultaneous determination of $\mathrm{Cd}(\mathrm{II})$ and $\mathrm{Pb}$ (II) were performed under optimized conditions at the bismuth film glassy carbon electrode prepared with the zinc mediator. For this purpose, measurements were taken in three cases: (1) constant concentration of $\mathrm{Pb}$ (II) and increasing concentration of $\mathrm{Cd}(\mathrm{II})$, (2) constant concentration of $\mathrm{Cd}(\mathrm{II})$ and increasing concentration of $\mathrm{Pb}$ (II) and (3) simultaneous increasing concentration of both metal ions. In the Table 1 the obtained results included linear working range, the linear regression equation, correlation coefficient (r), limits of detection and quantification are shown. The detection and quantification limits of $\mathrm{Cd}(\mathrm{II})$ and $\mathrm{Pb}(\mathrm{II})$ were calculated on the basis of 3 and 10 times the standard deviation $(n=3)$ for the lowest determined concentrations of $\mathrm{Cd}(\mathrm{II})$ and $\mathrm{Pb}(\mathrm{II})$ and divided by the slope of the linear regression equation, respectively. 
Table 1. The results obtained at the BiFE during calibration graphs construction for: (1) $\mathrm{Cd}(\mathrm{II})$ in the presence of constant concentration of $\mathrm{Pb}$ (II) $\left(5 \cdot 10^{-8} \mathrm{~mol} / \mathrm{dm}^{3}\right)$; (2) $\mathrm{Pb}$ (II) in the presence of constant concentration of $\mathrm{Cd}(\mathrm{II})\left(5 \cdot 10^{-7} \mathrm{~mol} / \mathrm{dm}^{3}\right)$ and (3) increasing concentration of $\mathrm{Cd}(\mathrm{II})$ and $\mathrm{Pb}(\mathrm{II})$.

\begin{tabular}{|c|c|c|c|c|c|}
\hline $\begin{array}{c}\text { The type of } \\
\text { calibration } \\
\text { graph }\end{array}$ & $\begin{array}{c}\text { Linear } \\
\text { working } \\
\text { range } \\
{\left[\mathrm{mol} / \mathrm{dm}^{3}\right]}\end{array}$ & $\begin{array}{l}\text { Linear } \\
\text { regression } \\
\text { equation }\end{array}$ & $\begin{array}{c}\text { Correlation } \\
\text { coefficient (r) }\end{array}$ & $\begin{array}{c}\text { LOD } \\
{\left[\mathrm{mol} / \mathrm{dm}^{3}\right]}\end{array}$ & $\begin{array}{c}\text { LOQ } \\
{\left[\mathrm{mol} / \mathrm{dm}^{3}\right]}\end{array}$ \\
\hline 1 & $\begin{array}{c}1 \cdot 10^{-8}- \\
5 \cdot 10^{-6}\end{array}$ & $y=4.73 x-0.13$ & 0.9987 & $4.76 \cdot 10^{-9}$ & $1.59 \cdot 10^{-8}$ \\
\hline 2 & $\begin{array}{c}2 \cdot 10^{-9}- \\
2 \cdot 10^{-6}\end{array}$ & $y=13.50 x-0.13$ & 0.9998 & $2.57 \cdot 10^{-10}$ & $8.56 \cdot 10^{-10}$ \\
\hline \multirow[b]{2}{*}{$\mathrm{Pb}(\mathrm{II})$} & $\begin{array}{c}1 \cdot 10^{-8}- \\
5 \cdot 10^{-6}\end{array}$ & $y=5.42 x+0.14$ & 0.9967 & $8.46 \cdot 10^{-10}$ & $2.82 \cdot 10^{-9}$ \\
\hline & $\begin{array}{c}2 \cdot 10^{-9}- \\
2 \cdot 10^{-6}\end{array}$ & $y=15.08 x+0.088$ & 0.9998 & $6.99 \cdot 10^{-10}$ & $2.33 \cdot 10^{-9}$ \\
\hline
\end{tabular}

$\mathrm{y}-$ peak current $[\mu \mathrm{A}]$

$\mathrm{x}$ - concentration of $\mathrm{Cd}$ and $\mathrm{Pb}\left[\mu \mathrm{mol} / \mathrm{dm}^{3}\right]$

\subsection{The application of the procedure in real water sample}

The optimized procedure was applied to the determination of $\mathrm{Cd}$ (II) and $\mathrm{Pb}$ (II) in water samples from the Vistula River. The cadmium and lead contents were estimated using the standard additional method. The determined concentration of $\mathrm{Cd}$ (II) in water sample was $3.50 \cdot 10^{-8}$ $\pm 0.39 \cdot 10^{-8} \mathrm{~mol} / \mathrm{dm}^{3}$ and $\mathrm{Pb}$ (II) was $8.09 \cdot 10^{-9} \pm 0.96 \cdot 10^{-9} \mathrm{~mol} / \mathrm{dm}^{3}$. The voltammograms obtained during the determination of $\mathrm{Cd}(\mathrm{II})$ and $\mathrm{Pb}(\mathrm{II})$ in the Vistula River sample are presented in the Figure 5. 


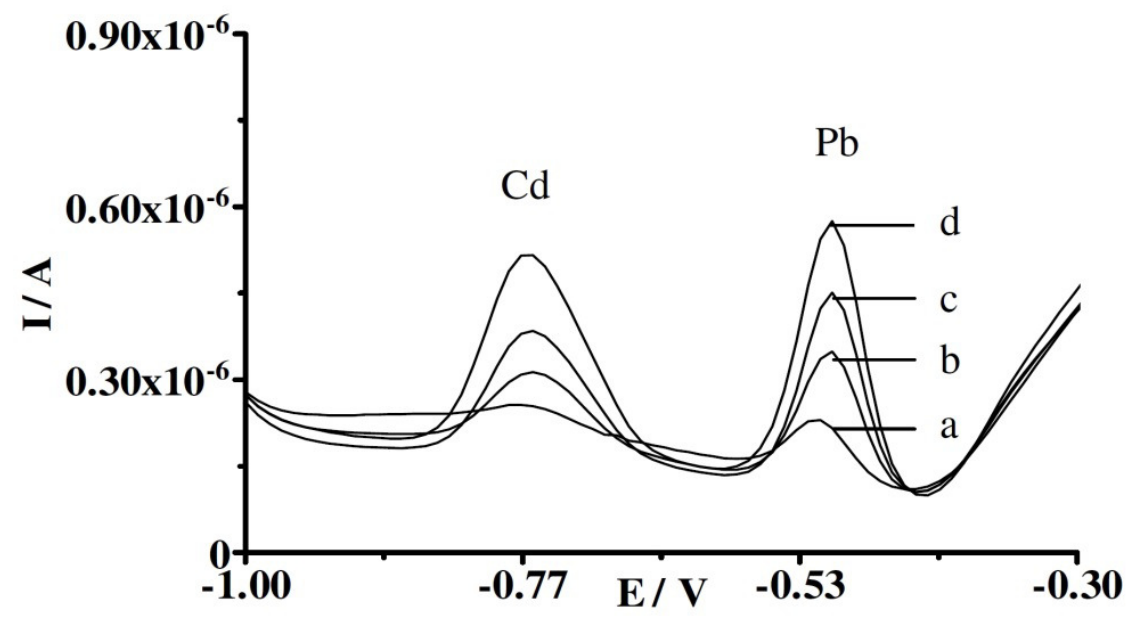

Fig. 5. Differential pulse anodic stripping voltammograms obtained during the determination of $\mathrm{Cd}(\mathrm{II})$ and $\mathrm{Pb}(\mathrm{II})$ in the Vistula River sample at the bismuth film glassy carbon electrode: a) sample $\left(9.4 \mathrm{~cm}^{3}\right)$; b) as (a) + $5 \cdot 10^{-8} \mathrm{~mol} / \mathrm{dm}^{3} \mathrm{Cd}$ (II) $+1 \cdot 10^{-8} \mathrm{~mol} / \mathrm{dm}^{3} \mathrm{~Pb}$ (II); c) as (a) $+1 \cdot 10^{-7} \mathrm{~mol} / \mathrm{dm}^{3}$ $\left.\mathrm{Cd}(\mathrm{II})+2 \cdot 10^{-8} \mathrm{~mol} / \mathrm{dm}^{3} \mathrm{~Pb}(\mathrm{II}) ; \mathrm{d}\right)$ as (a) $+1.5 \cdot 10^{-7} \mathrm{~mol} / \mathrm{dm}^{3} \mathrm{Cd}(\mathrm{II})+$ $3 \cdot 10^{-8} \mathrm{~mol} / \mathrm{dm}^{3} \mathrm{~Pb}(\mathrm{II})$.

\section{CONCLUSION}

The optimized procedure for the simultaneous determination of $\mathrm{Cd}(\mathrm{II})$ and $\mathrm{Pb}(\mathrm{II})$ at an environmentally friendly bismuth film glassy carbon electrode prepared with the use of a zinc mediator provides low limits of detection and wide linear ranges of the calibration graphs. The application of the zinc mediator contributes an enhancement of cadmium and lead peak currents. Moreover, the application of the procedure gives satisfactory results during the quantification of $\mathrm{Cd}(\mathrm{II})$ and $\mathrm{Pb}$ (II) in the river water sample.

\section{ACKNOWLEDGEMENT}

The project was financed from the resources of the Polish National Science Centre, and was awarded on the basis of decision No. DEC2013/08/M/ST4/00286. 


\section{REFERENCES}

[1] A. N. Kawde, Desalin. Water Treat., 57, 15697, (2016).

[2] S. Elatrash, N. Atoweir, Int. J. Chem. Sci., 12, 92, (2014).

[3] S. Lee, S. K. Park, E. Choi, Y. Piao, J. Electroanal. Chem., 766, 120, (2016).

[4] R. A. Segura, J. A. Pizarro, M. P. Oyarzum, A. D. Castillo, K. J. Díaz, A. B. Placencio, Int. J. Electrochem. Sci., 11, 1707, (2016).

[5] N. Serrano, A. González-Calabuig, M. del Valle, Talanta, 138, 130, (2015).

[6] L. Chen, Z. Li, Y. Meng, P. Zhang, Z. Su, Y. Liu, Y. Huang, Y. Zhou, Q. Xie, S. Yao, Sensor. Actuat. B-Chem, 191, 94, (2014).

[7] P. B. Tchounwou, C. G. Yedjou, A. K. Patlolla, D. J. Sutton, Mol. Clin. Environ. Toxicol. 101, 133, (2012).

[8] V. Mudgal, N. Madaan, A. Mudgal, R. B. Singh, S. Mishra, Open Nutraceuticals J., 3, 94, (2010).

[9] L. Järup, Brit. Med. Bull., 68, 167, (2003).

[10] G. Flora, D. Gupta, A. Tiwari, Interdiscip. Toxicol., 5, 47, (2012).

[11] P. J. Landrigan, Br. J. Ind. Med., 46, 593, (1989).

[12] A. Ociepa-Kubicka, E. Ociepa, Inżynieria i Ochrona Środowiska t. 15, 2, 169, (2012).

[13] K. Steenland, P. Boffetta, Am. J. Ind. Med., 38, 295, (2000).

[14] M. K. Siddiqui, S. Srivastava, P. K. Mehrotra, Biomed. Environ. Sci., 15, 298, (2002).

[15] T. I. Lidsky, J. S. Schneider, Brain, 126, 5, (2003).

[16] M. Sikirić, N. Brajenović, I. Pavlović, J. L. Havranek and N. Plavljanić, Czech J. Anim. Sci., 48, 481, (2003).

[17] J. Wang, Electroanal., 17, 1341, (2005).

[18] D. Yang, L. Wang, Z. Chen, M. Megharaj, R. Naidu, Electrochim. Acta, 132, 223, (2014).

[19] T.M. Florence, J. Electroanal. Chem. Interfacial Electrochem., 27, 273, (1970).

[20] J. Barek, A. G. Fogg, A. Muck, J. Zima, Crit. Rev. Anal .Chem., 31, 291, (2001).

[21] J. Wang, B. Tian, Anal. Chem., 65, 1529, (1993).

[22] J. Wang, J. Lu, Ü.A. Kirgöz, S.B. Hocevar, B. Ogorevc, Anal. Chim. Acta, 434, 29, (2001).

[23] K. Tyszczuk-Rotko, R. Metelka, K. Vytřas, M. Barczak, Electroanal., 26, 2049, (2014).

[24] K. Tyszczuk-Rotko, R. Metelka, K. Vytřas, M. Barczak, I. Sadok, B. Mirosław, Monatsh. Chem., 147, 61, (2016).

[25] K. Tyszczuk-Rotko, Electroanal., 7, 321, (2012). 